\title{
Conclusion
}

Democracy feeds from people's participation in their own governance (Lincoln 2009 [1863]). That would, from the maximalist approach to democracy, require citizens' participation in the decision-making processes of matters concerning them (Lipset and Lakin 2004, p. 20; Ewald 2013 , p. 52). One way this is done is through citizens' participation in public debates within a democratic public space, what Habermas (1989) refers to as the public sphere. In today's large democracies, the media serves as a space for public debates with the hope that through such debates, it can impact on policy decisions. The normative expectation is that the media ought to serve as a democratic public sphere, not only during debates about other institutions in society but also during debates about their policy. Aforementioned studies contend that this has not been the case (Stiegler 2013; Carlson and Berkowitz 2014). The susceptibility of the media to exploit their power as the facilitators of the public sphere to promote their views above those of other stakeholders during debates about their policy gives relevance to the study of the coverage on media policy debates.

The study of the coverage of media policy debates thus serves as an accountability system to check abuse of this public sphere by the media during debates about their policy. The NoTW phone hacking scandal provided an opportunity for this study because it stirred up a debate on press reform that was widely covered by the press. Broadly speaking, the book attempted to show how the media covered the press reform debate that

(C) The Author(s) 2020

B. Ogbebor, British Media Coverage of the Press Reform Debate, https://doi.org/10.1007/978-3-030-37265-1_11 
arose from the NoTW phone hacking scandal and the Leveson Inquiry. Its hope was that in the process, it would provide information for stakeholders (including members of the public, policymakers, campaigners for media reform and academics, amongst others) on how to ensure effective media reform in addition to enlightening readers on how to consume metacoverage on media policy. Let me pause here to briefly explain how the terms "metacoverage", "metajournalistic discourse" and "journalistic metadiscourse" were used in this book.

In this book, metacoverage refers to all types of self-coverage by the media. In Chap. 5, I argued that because of the original meaning and composition of the word, it should not be limited to journalists covering themselves during political campaigns as used by previous scholars (Esser et al. 2001). As explained in Chap. 5, the word "meta", in this context, is a Greek preposition meaning “with, after" (Liddell et al. 2015 [1883]). The use of the word as a prefix in the English language became popular in the nineteenth century. Examples are words like "meta-thorax", "metaphor" and "metabolic" (Dixon 2014, pp. 165-166). It also metamorphosed into the term "self-referential". One way in which it is used is that "a meta-X is an "X" describing an "X" (ibid.). An example is metadata which means data about data (Baca 2008, p. 1). In this book, I argued that considering the composition of the word "metacoverage" (coverage about coverage) and the fact that self-referential media coverage is diverse, the word can adequately be used as an umbrella term for all forms of selfreferential coverage by the media. Based on this, this book advocates that metacoverage be defined as all forms of self-referential coverage by the media.

Going by that definition, the discussion in this book falls within the category of metacoverage in the field of journalism, what Brin and Drolet (2009, p. 271) described as journalistic metadiscourse. I explained, in Chap. 5, that journalistic metadiscourse is what Carlson (2015) referred to as metajournalistic discourse on journalistic platforms (see Chap. 5). My analysis of the journalistic metadiscourse of the press reform debate was based on a study of how the debate was covered in six of the top ten British national newspapers (based on combined print and online readership figures for April 2011 to March 2012, NRS PADD 2012), two from each class of newspaper (at the time of investigation). For quality newspapers, I examined Guardian and Daily Telegraph; representing the midmarkets were Daily Express and Daily Mail, and for the red top tabloid newspapers, I examined The Sun and Daily Mirror. 
The research used the method of content analysis and some principles from critical discourse analysis to investigate how these newspapers covered the media reform debate. The results revealed that there were two spheres of discourse in the press coverage of the debate. The spheres of discourse were referred to, in this book, as sub-interpretive spheres. The Sun, Daily Mirror, Daily Express, Daily Mail and Daily Telegraph made up one sub-interpretive sphere while Guardian advanced the second sphere of discourse. The sphere to which many of the newspapers belonged interpreted press freedom based on neoliberal ideologies which advocated press self-regulation without state interference. While the second subinterpretive sphere consisting of the Guardian newspaper welcomed state interference in the form of a statute-backed press regulatory body, arguing that minimal state intervention in press regulation to check press accountability would not result in a loss of press freedom. I argued that the Guardian's style of coverage of the press reform debate leaned towards a social democratic approach.

Analysing findings from my investigation based on these two spheres helped to reveal the major division in the press' attempt to maintain, assert and/or renegotiate their professional boundaries through journalistic metadiscourse in the aftermath of the NoTW phone hacking scandal. The grouping of newspapers into spheres of discourse does not mean there were no differences among newspapers within the same sphere. What it means is that newspapers in the same sphere had similar interpretations on major issues in the debate. The uniqueness and difference in interpretation of each of the newspapers were also considered in the analysis. In showing how the debate was covered, I explored how paradigm repair strategies were used in the coverage, the extent to which they were used, the way sources were used, how blame was attributed and the quality of space given to the various arguments in the coverage of the press reform debate that followed the phone hacking scandal.

My investigation revealed that the press used five paradigm repair strategies to protect as well as repair its "press freedom" and "crusader image" paradigms. In agreement with the findings of Thomas and Finneman (2014), this study found that the press used the strategies of (1) "threat to the paradigm" (warning of threats to journalism's paradigms, also catastrophisation); (2) “self-assertion" (affirming journalism's value to a democratic society); (3) "minimisation" (downplaying the significance of the phone hacking scandal and therefore questioning the legitimacy of the inquiry) and (4) "individualisation" (localising the damage to acts 
committed by a handful of journalists, also bad apples or localisation) in their representation of the press reform debate. I added to this a fifth one, the strategy of "historicisation" (using history to explicate contemporary meaning [in this case, the press' preferred meaning]).

"Threat to the paradigm" was the dominant paradigm strategy used in the coverage. All newspapers examined in my investigation, apart from Guardian, used a high percentage of their space to warn that any form of state intervention in press regulation was a threat to press freedom. Linguistic devices such as hyperboles, "you centeredness" or direct address, adjectives and doom-laden rhetoric were used to spread the warning that press freedom was under attack. This affirms that when media scandals lead to calls for further regulation of the press, the resultant debate is often constructed in journalistic metadiscourse as a threat to press freedom (Carlson 2012; Steel 2012). While not completely ruling out the existence of such threats, consumers of journalistic metadiscourse will need to take into consideration the political economy behind such claims.

In Chap. 6, I showed how the coverage featured a blame game demonstrating a lack of willingness to accept change to the status quo. Blame was first accepted before self-exoneration strategies (individualisation, bad apples, localisation) were used to deflect the blame to other institutions, journalists or media organisations. For instance, blame for the phone hacking scandal was attributed to the criminal justice system, the Press Complaints Commission (PCC), other newspaper proprietors, politicians, technology, job constraints and commercialism. So, though there was wide acknowledgement of wrongdoing by the press, such acknowledgements only served as platforms from which blame was deflected to others. This made the high percentage of attribution of blame to journalists appear hypocritical. In Chap. 7, I argued that the apologies were probably a PR stunt to attract forgiveness from the public in other to retain their patronage. The strategy of historicisation was used in a similar fashion. It was used to acknowledge press bad behaviour, but in some cases, the detailed description of the bad behaviour served as infotainment (information designed to entertain). Infotainment can be detrimental to democracy because it can lead to the dumbing down of news and make the public a consumer audience, whose appetite is assuaged by such coverage (McManus 1994, p. 24; Franklin 1997). This can distract the public from active participation in efforts at reforming the press. 
My investigation also revealed that measures aimed at ensuring press accountability were interpreted in the sub-interpretive sphere comprising The Sun, Daily Mirror, Daily Express, Daily Mail and Daily Telegraph as unfair, illegitimate, unnecessary, a waste of resources, harmful to the reputation of the country and motivated by a thirst for revenge. This book showed that the strategy of minimisation (see Chap. 5) was used to achieve this. It was used to denigrate people and institutions that advocated any policy perceived as not being in the interest of the commercial press. Among those de-legitimised were the Leveson Inquiry, the Royal Charter on press self-regulation, politicians, victims of press abuse and campaigners for victims of press abuse. The press' minimisation of opposing views, along with the arguers of such views, shows how the media take advantage of their position as the facilitators of the public sphere to trivialise and denigrate efforts at reforming the press in a bid to prevent checks on news gathering methods that may destroy lives while generating high readership, power and money (McChesney 2008, p. 451). Measures aimed at ensuring press accountability were described as a "chilling effect on investigative journalism", "state control", "slippery slope to licensing of the press" and a loss of "300 years of press freedom". From these constructions, it can be seen that efforts at reforming the press were mostly portrayed in a negative light. The Guardian newspaper challenged most of these representations, and especially the claim that a statutorily backed press regulatory body would result in a loss of " 300 years of press freedom". However, it did not sign up to the Royal Charter on press regulation, raising doubts questions about the motive of its position in the media reform debate.

The strategy of self-assertion (also self-affirmation or self-justification) emerged as a minor theme designed to assert the importance of journalism within articles that stressed that a statutorily backed regulatory body would pose a threat to press freedom. This strategy was also used to protect the crusader image of the press when it comes under attack because of deviant behaviour. For example, when the Guardian realised that News of the World may not have deleted the voicemail of Milly Dowler as the paper had earlier published, the strategy of self-assertion was used to highlight the crusader attributes of the paper. When such self-affirmations emerge in journalistic metadiscourse on media reform debates, it is very likely that some error has been committed.

In terms of access to the media's public sphere, this book argues that the coverage of media reform debates features a doubly narrow spectrum 
of sources. I described it as "doubly narrow" because the range of sources was narrow, and within the narrow spectrum, press-related sources dominated the discourse. The sources used were categorised into press-related sources, policymakers, sources related to press abuse victims, Leveson and the Royal Charter, the judiciary, the police, academics, business organisations and ordinary members of the public (any individual not linked to a corporate body). The content analysis results showed that press-related sources were the most used (46.1 per cent) while ordinary citizens were the least used ( 1.6 per cent), demonstrating that the press gave disproportionate access to its own interpretations in the debate, to the detriment of the arguments of other stakeholders. I critiqued the representation of victims as "the stakeholders" rather than "a stakeholder" of the debate. While acknowledging the importance of the victims to the debate, I argued that limiting the stakeholder status to those who had been hurt by the press results in a limited range of views and risks shutting down more neutral voices that could have enriched the press reform debate.

The coverage followed a trend in which arguments perceived to be in the media's self-interest were given more quality space (high up in the narrative structure) than those considered to be against their interest. For example, "press freedom" featured more frequently than any other theme at the top of the narrative structure while arguments "against selfregulation" and "against the new press regulation formed by the press" were among issues that had the least appearances at the top of the narrative structure. This is one example of how the gatekeeping powers of the media are prone to abuse when the media cover debates about their policy. This privileging of the press over other stakeholders in the media policy debate was more prominent in The Sun, Daily Mirror, Daily Express, Daily Mail and Daily Telegraph than in Guardian newspaper. I argue that this manner of coverage can have an adverse effect on efforts at ensuring effective media reform because the bulk of the arguments that gets transmitted to the public may be those that protect the status quo in media regulation.

The issue of "public trust" received only minimal coverage, showing the need to give this issue more attention in debates about press standards. There were some alternative views in the debate that can be further explored. They include the need to make press membership to a reformed press regulatory body compulsory by law, enforce existing laws on crimes such as phone hacking, strengthen checks on concentration of media ownership, allocate more time to discussions on media reform and promote cultural revolution of journalists and proprietors. Unlike what Stiegler 
(2013, p. 137) found with the coverage of net neutrality in 2010, the media policy debate that followed the phone hacking scandal received very wide coverage in the press. While the overall wide coverage is commendable, a close look at the number of articles from each newspaper reveals an uneven amount of coverage among the newspapers. The bulk of the articles came from Guardian newspaper (323 out of 870). It was followed by Daily Telegraph with 199 articles and Daily Mail with 173 stories. The Sun, Daily Mirror and Daily Express were not that liberal with their coverage of the media policy debate having only 96,51 and 28 news articles on the debate, respectively. The implications of the overall coverage will be the focus of the next section.

\section{Coverage of Media Policy}

The way the media covered the press reform debate that emanated from the News of the World phone hacking scandal reveals trends in the coverage of media policy that warrant scrutiny because from an understanding of the manner of coverage would come insight into how to manage the coverage of media policy in such a way that it does not weaken media reform. Clearly, the press did not serve as democratic public sphere in its coverage of the debate. Instead, the press used its gatekeeping powers to advance its own views while limiting or preventing arguments which were against its self-interest from gaining entrance into the public sphere. It can be argued that this reduced the quality of the debate on press reform by inhibiting the kind of robust deliberations that produce plurality of views on media reform (ibid., p. 36). What emerged was a manner of coverage in which diverse paradigm repair strategies were used by the commercial press to give prominence to a discourse based on neoliberal ideologies where the press can only be self-regulated and where government must not intervene in press regulation if the press must be free to hold power to account.

Proponents of social democracy argue that this neoliberal conceptualisation of press freedom primarily serves the business interest of media owners who use the "threat to press freedom" argument as a weapon against any form of regulation that restricts their ability to invade the privacy of public figures in search of scoops that will improve the sale and readership of their papers (Pickard 2015, p. 4), what Curran and Seaton (2010) described as a struggle to maintain "power without responsibility". 
While I agree that the press should be free from state control in order to serve as the watchdog of the powerful in society, I am also of the view that some level of statutory regulation can enhance rather than inhibit democracy (Cushion 2012, p. 198; Heywood 2017, p. 123). However, the focus of this book is not to advocate either social democratic or neoliberal perspectives but to contend that the media ought to serve as a democratic public sphere, a space where robust debates on diverse perspectives of media reform can hold. Such robust debates have the capacity to produce quality approaches to media reform. Neoliberal perspectives ought not to be hegemonic in debates about media policy.

However, this book documented that Guardian newspaper toed the social democratic line of argument, arguing that a little dab of statute to prevent the Royal Charter from being abrogated easily (the law establishing it cannot be repealed without a two-thirds majority from both Houses of Parliament) will not amount to a loss of press freedom. As I pointed in Chap. 5, the fact that Guardian newspaper challenged the neoliberal perspectives of the other newspapers demonstrates that there was some level of diversity in the coverage, but the level of diversity was minimal. Though it can be argued that Guardian had a high amount of coverage (323 out of 870 news articles) on the debate, it is important to note that all of its articles were read by only its print readership of 4.06 million between 2011 and 2012 (readership figures for April 2011 to March 2012, NRS PADD 2012). As stated earlier, even with its combined print and online readership of about nine million, the circulation of Guardian is much lower than the combined readership of the other five newspapers: 20.5 million print and 49.4 million combined print and online readership (readership figures for April 2011 to March 2012, NRS PADD 2012). This coverage reveals an imbalance in the potential power of influence between the neoliberal and the social democratic press. The danger this poses to democracy is that neoliberal perspective will dominate the public sphere producing a narrow spectrum of views. And as Cushion (2018) has shown, the influence of the print media goes beyond its readership because it sometimes serves as a secondary source of information to the British broadcast media. Therefore, such manner of coverage can result in popular support for policies that are based on only neoliberal views, even when those views are based on self-interest.

And, indeed, the promotion of self-interest was evident in the coverage. Arguments perceived as not being in the interests of the press were accorded a weak position in the hierarchy of importance in news narrative; 
alternative views were blocked out and paradigm repair strategies were used to protect news paradigms. All these combined to keep quality options that could have provided effective checks on press power. What emerged was a zero-sum game of "statutory" or "no statutory" regulation. Several other options and alternative views were not explored. For example, despite its huge potential to do so, there was not much talk about how the public could help to reform the press.

The length the commercial press went to protect its neoliberal perception of press freedom is disturbing. The study of the coverage highlighted the enormous gatekeeping powers in the hands of the press and its ability to use them to its advantage to the detriment of any person or institution that dares to rise against it (Stiegler 2013, p. 137). There is obviously a need for such powers to come under check because they have the potential to give birth to autocracy and inequality in society (Rozell and Mayer 2008 , p. 328). Steps need to be taken to ensure that the press serves as a democratic public sphere not only when it covers other institutions, but also when it covers debates about its policies.

This book recommends that measures to ensure a democratic public sphere should come from within and outside the press. From within, the press needs to make conscious efforts to ensure that it serves as a democratic public space during debates about its policies. That means the range of sources should be more diverse to represent all sections of society; the press should not take undue advantage of its position as the facilitator of the public sphere to dominate the discourse; key issues of concern in the debate should be given proportionate space in the news narrative; and the conceptualisation of "the stakeholders of the press" should be expanded to include more neutral voices outside celebrities and other victims of press abuse. Taking the position that the ownership structure was responsible for the emergence of two sub-interpretive spheres, I recommend that efforts to diversify news content should go beyond plurality of owners to plurality of business models.

However, I acknowledge that drawing up a list of recommendations for the press to follow does not axiomatically translate into a cultural revolution of the press. It will require willingness on the part of the press to become a democratic public sphere before it can adopt any of these recommendations. This book recognises the challenge in asking the press to serve as a democratic public sphere during debates about themselves because bias is inevitable and every organisation or industry may exhibit some level of bias in its own favour (Elmessiri 2006, p. 49; Livermore 
2011 , p. 50). However, the fact that bias is inevitable does not mean action cannot be taken to check bias in self-coverage. That is why steps to make the press accountable should also come from outside the press. Many appear to have recognised this fact but have narrowed their gaze to the state as being the only custodian of the public interest (Heywood 2017 , p. 123). It is high time the public took their place as major custodians of their own interest.

One media accountability system with huge potential to reform the press, yet is underexplored, is non-governmental public reformism. Public reformism seeks to improve the standard and viability of journalism through concerted action (Curran 2011, p. 31), such actions as could enhance the democratic performance of the media. Examples of such actions include strategies to promote a public interest culture among professional journalists, the public ownership and funding of leading broadcasting organisations, subsidising minority newspapers, public action to support independent news production and giving vouchers to citizens for annual donation to a news medium of their choice who has fulfilled some public interest function including offering free access to online news (ibid.).

In agreement with Curran's call for public reformism (ibid.), Pickard suggests that public media be strengthened to sustain the journalism that the commercial media no longer supports (Pickard 2015, pp. 228-231). Freedman (2014, pp. 104-106) also recognises the power of the public to reform the press and induce it to fulfil its role in the sustenance of democracy. According to Freedman, "developments like the internet have not only undermined the power of the traditional gatekeepers but have put in their place, a 'public society' to which there can be no meaningful resistance" (ibid.). Jarvis (2011) puts it this way:

Publicness is a sign of our empowerment at their expense. Dictators and politicians, media moguls and marketers try to tell us what to think and say. But now in a truly public society, they must listen to what we say. (Jarvis 2011, p. 11)

Despite the threat of oligopoly and manipulation of online platforms by corporate internet giants like Google and Facebook alongside other elite voices, the power of the public to serve as a force for media reform is still very tangible (Castells 2013). In his The Contradictions of Media Power, Freedman (2014, pp. 25-30) acknowledged the power of the public to 
reform the press. One area of public reformism that has not been much explored is public reformism without government intervention. A major component of public reformism that is void of government intervention is "the willpower of the public". Willpower is defined by McGonigal (2011, p. 8) as "the ability to control our attention, emotion, and desires". Riley $(2011$, p. 3) views willpower as "the attitude of the mind which is directed with conscious attention to some action". Willpower has often been analysed in terms of self-control: how to break bad habits such as overcoming addictions, eating less and sticking to your resolutions. Most of these are things that relate to the individual's self-development. This is what I refer to as "willpower as an internal force for self-development".

But willpower can also be used to change societies (Baumeister and Tierney 2012). That is what I refer to as "willpower as an external force for societal development". In line with the argument of some psychologists (McGonigal 2011; Riley 2011, pp. 1-2; Taylor 2017) that willpower can be used to "create the life you want", I argue that the public can direct their willpower to create the press they want. The saying "we get the press we deserve" (Gladstone et al. 2011; Boston 2015) makes sense when viewed under the lenses of willpower. It can therefore be argued that the public's inaction and/or action have played a major role in the manner of press we have and can play a major role in what it becomes. The public has power to reform the press. That is not to say the public is the sole solution to all forms of degeneration in the public sphere. What it means is that the public can play a key role in ensuring an accountable press, the kind of press that can efficiently serve democracy. The public is not the helpless and powerless victim of press power as some have described them (Salter 2007). The problem is that the public is yet to fully grasp the enormous power it possesses, one which can be used to effectively reform the press. As Tom Baistow pointed out:

There is no shortage of ideas, as the evidence of the Royal Commission showed. Only the will is lacking. If we don't generate that among both public and parliament we shall end up with the press we deserve, but the press no real democracy can afford. (Baistow 2015 [1970], p. 56)

Baistow observed that "it will take considerable time and a conscious, organized effort to educate" the public to use their willpower for press reform (ibid.). McGonigal (2011) found that the brain can be trained for greater willpower. Similarly, Baumeister and Tierney $(2012$, p. 1) show us 
that willpower is like a muscle that can be strengthened with practice. All these go to show that with adequate enlightenment, orientation and sensitisation, the public can recognise their power to reform the press and use it effectively. The willpower of citizens can be used to purchase or not purchase newspapers; to visit or not to visit a news website; to boycott the patronage of a newspaper in diverse ways and so on. In fact, the 2019 Guardian's financial success was largely attributed to the public. Waterson (2018) wrote, "The Guardian and the Observer have broken even for the first time in recent history aided by record online traffic, reduced costs and increased financial contributions from readers". The public can decide to fund public interest journalism through such contributions.

There have been other instances in the past where the public has used its willpower to challenge press excesses or perceived misconduct. An example is the reaction of the public to The Sun newspaper's coverage of the 1989 Hillsborough disaster in which 96 football fans died (Scraton 2005 , pp. 62-74; 2016). In Liverpool, members of the public and nongovernmental groups such as anfieldroad.com and the Hillsborough Justice Campaign (HJC) staged boycotts against The Sun newspaper to protest the paper's publication of false information blaming Liverpool football fans for the Hillsborough disaster (Anfield Road 2007; Contrast. org 2017a, b; Conn 2017). Another instance is the public outcry against the News of the World for hacking into the voicemail of murdered school girl Milly Dowler, in addition to other acts of phone hacking (see Chap. 1). The public outrage and its publicity resulted in advertisers withdrawing patronage and the eventual closure of the newspaper in July 2011.

Non-governmental agencies can also choose to ban reporters of errant newspapers from covering their programmes especially where such programmes sell. An example is Everton Football Club who banned The Sun newspaper journalists from their football stadium, Goodison Park, and their Finch Farm training ground after one of The Sun's columnists, Kelvin MacKenzie (it so happened that this same person was the paper's editor at the time of the Hillsborough incident), likened one of their players, Ross Barkley, who is of mixed race, to a gorilla (Parveen 2017).

In all the examples, public outrage drew apologies from the newspapers involved and touched one of their soft spots - their readership (Cozens 2004). In the case of the News of the World, they paid the ultimate priceclosure. It would, however, be stretching willpower too far if it is used indiscriminately to frustrate media organisations out of business. As Baumeister and Tierney $(2012$, p. 1) discovered, there can also be 
excessive use of willpower. Effective discipline is one that leads to change not destruction. With the decline in the sales of newspapers (the circulation of UK national dailies plunged from 11.5 million daily copies in 2008 to 5.8 million in 2018), media reform needs to ensure that it averts rather than enhances the death of newspapers (Department for Digital, Culture, Media and Sport 2019, pp. 25-26). Frequent closures of newspapers will not be beneficial to citizens, society, the economy, media owners and even democracy. That is because it could result in side effects including job losses, a consequent increase in the number of employment benefit recipients and reduced diversity in media platforms.

The need for adequate education on how willpower can be used by the public to reform the press cannot be overemphasised. Non-governmental charities for public interest journalism and journalism institutions can develop a curriculum on how to train members of the public to exercise their power to check press accountability in an informed and productive manner. Care needs to be taken to see that such powers are not hijacked and abused by groups with selfish motives. I do not claim that public reformism will completely eradicate press excesses. What I argue is that sustained and well-managed pragmatism on the part of the public can keep the press in check to a considerable degree. As Stiegler (2013, p. 139) puts it, "With a vocal public who willingly air their grievances, news media are more likely to adhere to ethical standards of journalism". The public can also develop themselves to understand how the press cover themselves (ibid., p. 138). This can enable them to recognise stories or arguments that are based on self-interest. An informed citizen can make a decision that can aid democracy just as ill-informed citizens can collectively work against democracy. Use of public willpower offers a method of press reform that excludes two potential self-interested parties (the press and the state). Public reformism is only one among several options that can emerge from a debate on media policy in a democratic public sphere. If well developed, taught and managed, non-governmental public reformism can emerge as one of the major ways of sustaining high-quality journalism.

While demanding good behaviour from a child considered to be a deviant [as with the press], it is important to listen to that child to know what he or she sees as impediments to good behaviour. The press has often attributed the increasing dumbing down of quality journalism in the UK to pressure to make ends meet due to loss of revenue caused by the exodus of readers and advertisers to social media who are not as stringently 
regulated as the mainstream media. The Cairncross Review acknowledged this as a challenge and made recommendations that if well implemented may help, to some extent, in this regard. The Cairncross Review was set up by the British government in 2019 to investigate the challenges facing high-quality journalism in the UK and to come up with recommendations that can help to secure its future (Department for Digital, Culture, Media and Sport 2019, p. 5).

\section{Sustainable Journalism and the Cairncross Review}

The Cairncross Review, which was commissioned by the UK government and led by Dame Frances Cairncross, aimed to find out as well as recommend ways of ensuring a sustainable future for high-quality journalism in the UK. To do this, the Review examined the state of "the news media market, the threats to the financial sustainability of publishers, the impact of search engines and social media platforms, and the role of digital advertising” (Department for Digital, Culture, Media and Sport 2019, p. 5). The Review received evidence from stakeholders of the media industry including journalists, academics, entrepreneurs and representatives of the media industry. Based on the evidence gathered, it concluded that "the news publishing business is undergoing an extraordinary period of contraction in both of its main traditional sources of revenue: advertising and circulation" (ibid.).

Elaborating on the seriousness of the threat to the continued existence of the printed press, the Cairncross Review pointed out that print sales of national and local newspapers have fallen by about 50 per cent in the last decade, between 2007 and 2017, and have continued to drop. The national newspaper daily circulation fell from 11.5 million in 2008 to 5.8 million in 2018 . The local newspaper weekly circulation fell from 63.4 million in 2007 to 31.4 million in 2017 while print advertising which was a major source of revenue fell by 69 per cent within the period. The Review pointed out that the proportion of UK adults who read print news each week has fallen from 59 per cent of the adult population in 2013 to 36 per cent in 2018. Majority of people now get news entirely or mostly online. Most online news is available for free and provided by "aggregators such as Google News or Apple News" or "posted on Facebook's news feed". As the Review emphasised: 
They are much less likely to see the mixed bundle of politics, finance, entertainment and sport that constitutes many papers, and more likely to see an individual story, chosen by a computer program and not necessarily clearly labelled with the name of a particular publisher. (Department for Digital, Culture, Media and Sport 2019, p. 6)

This manner of news consumption, it argues, has implications for the visibility of public interest news and for trust in news.

Despite the fact that public trust for newspapers was more than that for social media (Department for Digital, Culture, Media and Sport 2019, p. 5), in 2018, 74 per cent of adults and 91 per cent of 18- to 24-year-olds in the UK searched for news online every week, (Reuters cited in Department for Digital, Culture, Media and Sport 2019, p. 6). The Review acknowledged that some mergers are as a result of dwindling revenues in the printed press industry. Dwindling revenue has also resulted in reduced staffing (from 23,000, in 2007 to 17,000 in 2019), closed local offices and lack of funds to invest in the transformations that are needed to stay relevant in the digital age (Department for Digital, Culture, Media and Sport 2019). As the Review noted, one person in ten in the UK now reads a regional or local printed paper each week (Department for Digital, Culture, Media and Sport 2019).

In sum, the Cairncross Review sought to find out if the market in which publishers operate is fair, considering the rapid growth of the big online platforms such as Google and Facebook and because traditional news media complained that these online platforms affect the market in such a way that warrants government intervention. As stated earlier, they had complained that online platforms take a large share of the market for advertising and provide the routes that many people use to find news online. The Cairncross Review was, therefore, expected to offer recommendations intended to create a better balance between publishers and platforms, and to persuade the online platforms to use their position in more accountable ways (ibid.).

The Cairncross Review recommends that online platforms (Google and Facebook, and possibly Apple) should be required to create codes of conduct that will govern their commercial arrangements with news publishers (Department for Digital, Culture, Media and Sport 2019, p. 10). A regulator which should have powers to insist on compliance will oversee the setting up of the code of conduct (ibid.). This regulator will include members with skills in economics and digital technology. Negotiations between 
publishers and online platforms can then be guided by this code. The Cairncross Review advised that "if the powers of the regulator proved insufficient, government should implement stronger measures" (Department for Digital, Culture, Media and Sport 2019, p. 10). The Review also recommends that the Competition and Markets Authority (CMA) should investigate the online advertising market to ensure fair competition (ibid.). Through a close examination of "the position of different players, their roles, costs and profitability, the CMA will be able to identify how efficiently the online advertising market is working, and what remedies, if any, are needed" (Department for Digital, Culture, Media and Sport 2019, p. 10).

The Review advised that online platforms' efforts at improving their users' news experience should be placed under regulatory supervision to ensure good quality news provision. The regulator will ensure that online platforms continue and expand the initiatives they have developed to help users identify reliability and trustworthiness of sources. The Cairncross Review recommends that the government should work with Ofcom, the online platforms, news publishers, broadcasters, voluntary organisations and academics to develop a media literacy strategy that would identify gaps in provision and opportunities for more collaborative work (Department for Digital, Culture, Media and Sport 2019, p. 10). Although the Review was not asked to comment on the $\mathrm{BBC}$, it advised that Ofcom should explore the BBC's market impact. It wants the BBC to do more to help local publishers, for example, using its technical and digital expertise to direct traffic from its online site to local publishers. The Review recommends that the government launch a fund to help news publishers meet the current need for innovations and transformations in print journalism in the digital era. This new fund will focus on innovations (new approaches and tools) aimed at improving the supply of public interest news. The fund would be managed by Nesta at the start, and in due course by the Institute for Public Interest News which the Review recommends (see later in this chapter).

The Cairncross Review advised the government to introduce two forms of tax relief "aimed at encouraging (1) payments for online news content and (2) the provision of local and investigative journalism" (Department for Digital, Culture, Media and Sport 2019, p. 10). Under this proposal, the zero-rating of VAT which already exists for the printed news formats will be extended to digital newspapers and magazines, including digitalonly news publications. The Review also recommends the creation of a 
form of tax relief, under the Charities Act, "but if necessary along the lines of the Creative Sector reliefs, to support public-interest journalism" (ibid.). Simply put, this tax relief involves "extending charitable status to non-profit publishers, who could then enjoy the significant tax advantages" (Townsend 2019, n.p.). This form of tax relief was first proposed by the Lords Communications Committee in 2012 (ibid.).

Direct funding for local public interest news was another recommendation made by the Review. This would entail the modification and expansion of the Local Democracy Reporting Service currently managed by the BBC. As of 2019, the BBC-managed Local Democracy Reporting Service sponsored 144 reporter contracts with local publishers but there have been complaints that only big regional publishers benefitted from the scheme. The Review advised that in due course, management of the service should be passed to, or shared with, the proposed Institute for Public Interest News. One of the key recommendations of the Cairncross Review was its call for the establishment of an Institute for Public Interest News. In collaboration with news publishers, the online platforms, Nesta, Ofcom, the BBC and academic institutions, this body will have the responsibility of promoting efforts aimed at ensuring the future sustainability of public interest news. Here, priority attention would be given to measures which incentivise the provision and consumption of public interest news. Funds for such incentives should emanate from a source that is free from direct government control.

It would be interesting to investigate the execution and outcome of these proposals in future research. How much of these recommendations would be implemented? Where implemented, to what extent did the implementation result in the sustainability of high-quality journalism? Media scholars such as Petley (2018) have called for more clarity in the Review's definition of high-quality journalism. Based on past and current outcomes from government's efforts on media policy, there are fears that the funding would end up as a boost to the mainstream printed press to the detriment of local publishers. As (Townsend 2019, n.p.) noted:

Ultimately, the usefulness of this review will stand or fall on whether the government is willing to face down a press lobby which is accustomed to flexing its muscles and - as the Leveson enquiry graphically demonstratedhas successfully bullied successive UK governments for decades. 
The sustenance of quality journalism is a top concern of stakeholders of media policy. The sustainability of high-quality journalism in the UK would require on the part of the press the facilitation of a democratic public sphere during their coverage of media policy debates; on the part of the public, knowledge of how to consume journalistic metadiscourse on media policy and more pragmatic participation in efforts at reforming the press; on the part of academics, developing innovative frameworks for nongovernmental public reformism; and on the part of the government, a commitment to implementing recommendations in such a way as to achieve their purpose.

Considering the wide readership of news from online platforms, possible research for future studies would be to investigate how online news platforms covered the debate. A comparative analysis between this mainstream coverage and the online coverage of the debate would be useful. Similarly, an empirical study of how the broadcast media covered the media policy debate would help to reveal the differences and similarities between the printed press and broadcast media coverage of media policy debates. The findings can be analysed against the backdrop of Cushion et al.'s (2018) study which revealed the enduring influence of the press agenda over the television news agenda. It would be helpful to find out if that is the case in media policy debates. This is significant because of the wide reach of a combination of the press and broadcast media in the UK. Having shown strategies adopted by the media in self-coverage, a study of how the public consumes journalistic metadiscourse would also provide an interesting area for further study. And finally, future research can also evaluate the implementation of the Leveson Report and the Cairncross Review to reveal the extent to which they fulfilled their purpose.

\section{REFERENCES}

Anfield Road. (2007). Liverpool FC. Unofficial. Independent. Free [Online]. Retrieved April 29, 2017, from http://www.anfieldroad.com/ dont-buy-the-sun/.

Baca, M. (2008). Introduction to metadata. Los Angeles: Getty Publications.

Baistow, T. (2015). Anatomy of a crisis. In R. Boston (Ed.), The press we deserve (pp. 41-56). London: Routledge and Kegan Paul.

Baumeister, R., \& Tierney, J. (2012). Willpower: Rediscovering our greatest strength. London: Penguin.

Boston, R. (2015). The press we deserve. London: Routledge and Kegan Paul.

Brin, C., \& Drolet, G. (2009). Tabloid nouveau genre. In B. Franklin (Ed.), The future of newspapers (pp. 262-277). London: Routledge. 
Carlson, M. (2012). On the condition of anonymity: Unnamed sources and the battle for journalism. Champaign, IL: University of Illinois Press.

Carlson, M. (2015). Metajournalistic discourse and the meanings of journalism: Definitional control, boundary work, and legitimation. Communication Theory, 26(4), 349-368.

Carlson, M., \& Berkowitz, D. (2014). 'The emperor lost his clothes': Rupert Murdoch, News of the World and journalistic boundary work in the UK and USA. Journalism, 15(4), 389-406.

Castells, M. (2013). Communication power (2nd ed.). Oxford: Oxford University Press.

Conn, D. (2017). Liverpool ban Sun journalists over Hillsborough coverage. Guardian, February 2017 [Online]. Retrieved April 29, 2017, from https:// www.theguardian.com/football/2017/feb/10/liverpool-ban-the-sunnewspaper-over-hillsborough-coverage.

Contrast.org. (2017a). Hillsborough football disaster: The immediate aftermath [Online]. Retrieved April 29, 2017, from http://www.contrast.org/hillsborough/history/media.shtm.

Contrast.org. (2017b). The boycott of Hillsborough [Online].. Available at: http:// www.contrast.org/hillsborough/boycott.shtm.. Accessed 29 Apr 2017.

Cozens, C. (2004). Sun apologises for Hillsborough. Guardian, 7 July 2004 [Online]. Available at:. https://www.theguardian.com/media/2004/jul/07/ pressandpublishing.football. Accessed 29 Apr 2017.

Curran, J. (2011). Media and democracy. London: Routledge.

Curran, J., \& Seaton, J. (2010). Power without responsibility: Press, broadcasting and the internet in Britain (7th ed.). London: Routledge.

Cushion, S. (2012). The democratic value of news: Why public service media matter. Hampshire: Palgrave Macmillan.

Cushion, S., et al. (2018). Newspapers, impartiality and television news: Intermedia agenda-setting during the 2015 UK general election campaign. Journalism Studies, 19(2), 162-181.

Department for Digital, Culture, Media and Sport. (2019). The Cairncross review: a sustainable future for journalism. 12 February 2019 [Online]. Available at: https://assets.publishing.service.gov.uk/government/uploads/system/ uploads/attachment_data/file/779882/021919_DCMS_Cairncross_ Review_.pdf. Accessed 3 July 2019.

Dixon, R. (2014). Making new words: Morphological derivation in English. Oxford: Oxford University Press.

Elmessiri, A. (2006). Epistemological bias in the physical and social sciences. London: International Institute of Islamic Thought (IIIT).

Esser, F., et al. (2001). Spin doctors in the United States, Great Britain, and Germany: Metacommunication about media manipulation. Harvard International Journal of Press/Politics, 6, 16-45. 
Ewald, J. (2013). Challenges for the democratisation process in Tanzania. Moving towards consolidation years after independence? Oxford: African Books Collective.

Franklin, B. (1997). Newszak and news media. London: Arnold.

Freedman, D. (2014). The contradictions of media power. London: Bloomsbury.

Gladstone, B., et al. (2011). The influencing machine: Brooke Gladstone on the media. New York: W. W. Norton.

Habermas, J. (1989). The structural transformation of the public sphere: An inquiry into a category of bourgeois society. Cambridge: Polity Press.

Heywood, A. (2017). Political ideologies: An introduction (6th ed.). London: Palgrave Macmillan.

Jarvis, J. (2011). Public parts: How sharing in the digital age improves the way we work and live. New York: Simon and Schuster.

Liddell, H., et al. [1883] (2015). A Greek-English Lexicon. California: Clarendon Press.

Lincoln, A. [1863] (2009). The Gettysburg address. London: Penguin.

Lipset, M. S., \& Lakin, M. J. (2004). The democratic century. Oklahoma: University of Oklahoma Press.

Livermore, D. (2011). The cultural intelligence difference: Master the one skill you can't do without in today's global economy. New York: AMACOM.

McChesney, R. W. (2008). The political economy of media: Enduring issues, emerging dilemmas. New York: NYU Press.

McGonigal, K. (2011). The willpower instinct: How self-control works, why it matters, and what you can do to get more of it. London: Penguin.

McManus, J. H. (1994). Market-driven journalism: Let the citizen beware? London: Sage.

NRS PADD. (2012). NRS print and digital data survey [Online]. Retrieved January 14, 2017, from https://www.theguardian.com/news/datablog/2012/sep/12/digital-newspaper-readerships-national-survey\#quality.

Parveen, N. (2017). Sun suspends Kelvin MacKenzie over column on Ross Barkley: Police investigating article that compared Everton footballer who was punched in a nightclub to a gorilla. Guardian 14 April.

Petley, J. (2018). What 'High Quality Journalism'? A response to the Cairncross review's call for evidence. Inforrm's Blog 21 September [Online]. Available at:https://inforrm.org/2018/09/21/what-high-quality-journalism-aresponse-to-the-cairncross-reviews-call-for-evidence-julian-petley/. Accessed 29 Aug 2019.

Pickard, V. (2015). America's battle for democracy: The triumph of corporate libertarianism and the future of media reform. Cambridge: Cambridge University Press.

Riley, G. (2011). Willpower!: How to master self-control. London: Random House. Rozell, M. J., \& Mayer, J. D. (2008). Media power, media politics (2nd ed.). Plymouth: Rowman \& Littlefield. 
Salter, D. (2007). The media we deserve: Underachievement in the fourth estate. Melbourne: Melbourne University Press.

Scraton, P. (2005). Death on the terraces: The context and injustices of the 1989 Hillsborough disaster. In P. Darby et al. (Eds.), Soccer and disaster (pp. 59-76). London: Routledge.

Scraton, P. (2016). Hillsborough - the truth. Edinburgh: Random House.

Steel, J., 2012. Journalism and free speech. London: Routledge.

Stiegler, Z. (2013). Regulating the web: Network neutrality and the fate of the open internet. Plymouth: Rowman \& Littlefield.

Taylor, R. (2017). Willpower: Discover it, use it and get what you want. Chichester: Wiley.

Thomas, R. J., \& Finneman, T. (2014). Who watches the watchdog? Journalism Studies, 15(2), 172-186.

Townsend, J. (2019). Could Cairncross help public interest law reporting? Inforrm's Blog 24 February 2019 [Online]. Available at: https://inforrm. org $/ 2019 / 02 / 24 /$ could-cairncross-help-public-interest-law-reportingjudith-townend/. Accessed 29 Aug 2019.

Waterson, J. (2018b). Leveson 2: Government to be taken to court over cancelled inquiry [Online]. Guardian, 21 May 2018. Available at: https://www.theguardian.com/media/2018/may/21/leveson-2-government-taken-courtover-cancelled-inquiry. Accessed 20 Aug 2018.

Open Access This chapter is licensed under the terms of the Creative Commons Attribution 4.0 International License (http://creativecommons.org/licenses/ by $/ 4.0 /$ ), which permits use, sharing, adaptation, distribution and reproduction in any medium or format, as long as you give appropriate credit to the original author(s) and the source, provide a link to the Creative Commons licence and indicate if changes were made.

The images or other third party material in this chapter are included in the chapter's Creative Commons licence, unless indicated otherwise in a credit line to the material. If material is not included in the chapter's Creative Commons licence and your intended use is not permitted by statutory regulation or exceeds the permitted use, you will need to obtain permission directly from the copyright holder.

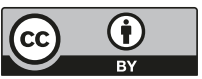

